on final fruit set on 'Greensleeves' apples. HortScience 20(3):400-401.

Lord, W.J., D.W. Greene, and R.A. Damon. 1975. Evaluation of fruit abscission and flower bud promotion capabilities of ethephon and SADH on apples. J. Amer. Soc. Hort. Sci. 100:259-261.

Luckwill, L.C. 1953. Studies on fruit development in relation to plant hormones. II. The effect of naphthaleneacetic acid on fruit set and fruit development in apples. J. Hort. Sci. 28:25-40.

MacDaniels, L.H. and E.M. Hildebrand. 1940. A study of pollen germination on the stigmas of apple flowers treated with fungicides. Proc. Amer. Soc. Hort Sci. 37:137-140.

Marini, R.P. 1996. Chemically thinning spur Delicious apples with carbaryl, NAA, and ethephon at various stages of fruit development. Hort. Technology 6:241-246.

McLaughlin, J.M. and D.W. Greene. 1984. Effects of BA, GA ${ }_{4+7}$, and daminozide on fruit set, fruit quality, vegetative growth, flower initiation, and flower quality of 'Golden Delicious' apple. J. Amer. Soc. Hort. Sci. 109:34-39.

McLaughlin, J.M. and D.W. Greene. 1991. Fruit and hormones influence flowering of apple. II. Effects of hormones. J. Amer. Soc. Hort. Sci. 116:450-453.

Miller, P. 1985. Apple thinning in Australia. Hort. Res. Inst., Knoxfield.

Schneider, G.M. and A.M. Lasheen. 1973. NAA and Sevin on composition, development and abscission of apple fruit. HortScience 8:103-104.

Schwallier, P.G. 1996. Apple Thinning Guide. Great Lakes Publishing Company, Sparta, Mich.

Southwick, F.W. and W.D. Weeks. 1949. Chemical thinning of apples at bloom time and up to four weeks from petal fall. Proc. Amer. Soc. Hort. Sci. 53:143-147.

Stopar, M., B.L. Black, and M.J. Bukovac. 1997. The effect of NAA and BA on carbon dioxide assimilation by shoot leaves of spur-type 'Delicious' and 'Empire' apple trees. J. Amer. Soc. Hort. Sci. 122:837-840.

Struckmeyer, B.E. and R.H. Roberts. 1950. A possible explanation of how naphthalene acetic acid thins apples. Proc. Amer. Soc. Hort. Sci. 56:76-78.

Thompson, A.H. 1957. Six years experiments on chemical thinning of apples. Univ. of Maryland Agr. Expt. Sta. Bul. A-88.

Tukey, L. 1965. Fruit-size timing in chemical thinning of apple trees. Proc.
Illinois Hort. Soc. 99:67-79.

Unrath, C.R. 1978. The development of ethephon's thinning potential for spur 'Delicious' apples. Acta Hort. 80:233-243.

Unrath, C.R. 1981. An overview of environmental factors affecting orchard growth regulator response with special reference to apple. Acta Hort. 120:43-52.

Wertheim, S.J. 1973. Chemical control of flower and fruit abscission in apple and pear. Acta Hort. 34:321-331

Westwood, M.N. and L.P. Batjer. 1958. Factors influencing absorption of dinitro- ortho-cresol and naphthaleneacetic acid by apple leaves. Proc. Amer Soc. Hort Sci. 72:16-29.

Westwood, M.M. and L.P. Batjer. 1960. Effects of environment and chemical additives on absorption of naphthanelenacetic acid by apple leaves. Proc. Amer. Soc. Hort. Sci. 76:16-29.

Westwood, M.N., L.P. Batjer, and H.D. Billingsley. 1960. Effects of environment and chemical additives on absorption of dinitro-o-cresol by apple leaves. Proc. Amer. Soc. Hort. Sci. 76:30-40.

Williams, M.W. 1993. Sulfcarbamide, a blossom-thinning agent for apples. HortTechnology 3:322-324.

Williams, M.W. 1994. Factors influencing chemical thinning and update on new chemical thinning agents. Compact Fruit Tree 27:115-122.

Williams, M.W. and L.P. Batjer. 1964. Site and mode of action of 1-naphthyl$\mathrm{N}$ - methylcambamate (Sevin) in thinning apples. Proc. Amer. Soc. Hort. Sci. 85:1-10.

Williams, M.W., S.A. Bound, J. Hughes and S. Tustin. 1995. Endothall: A blossom thinner for apples. HortTechnology 5(3):257-259.

Williams, M.W. and L.J. Edgerton. 1981. Fruit thinning of apples and pears with chemicals. U.S. Dept. Agr. Bul. 289, Washington, D.C.

Wismer, P.T., J.T.A. Proctor and D. C. Elfving. 1995. Benzyladenine affects cell division and cell size during apple fruit thinning. J. Amer. Soc. Hort. Sci. 120:802-807.

Yuan, R. and D.W. Greene. 2000. Benzyladenine as a chemical thinner for 'McIntosh' apples. I. Fruit thinning effects and associated relationships with photosynthesis, assimilate translocation, and nonstructural carbohydrates. J. Amer. Soc. Hort. Sci. 125:169-176.

\title{
Spray Volume, Canopy Density, and Other Factors Involved in Thinner Efficacy
}

\author{
C.R. Unrath ${ }^{1}$ \\ Department of Horticulture Science, North Carolina State University, \\ Mountain Horticultural Crops Research and Extension Center, 455 Research Drive, Fletcher, NC 28732
}

Historically, a single, arbitrary water volume was used for most airblast chemical applications to apple (Malus $\times$ domestica Borkh.) orchards. Chemical recommendation rates were originally based on a "mythical" $3741 \mathrm{~L} \cdot \mathrm{ha}^{-1}$ water volume for "mature bearing trees". In the early 1970s, we were at a loss to explain the wide variability in chemical thinning response among grower locations to similar treatments (Herrera, 1977). After reviewing an article (Byers, et al., 1968), where canopy volume was related to water volume to illustrate to growers that smaller trees required less water volume than the "mythical, mature bearing" size tree for good pesticide coverage, we began to focus on the relationship of tree size to water volume to explain variability in response to chemical thinners.

Adjustment of water volume to tree size removed the treatment by location interaction in thinning research plots, and for the first time allowed evaluation of mean chemical response over locations (Herrera, 1997). Thus, this "tree row volume" (TRV) concept was developed (Herrera and Unrath, 1980). Subsequently, we found that water volumes used by growers did not vary with tree size. Therefore, most growers were overspraying small trees and underspraying large ones (Sutton and Unrath, 1984).

Received for publication 17 Mar. 1988. Accepted for publication 29 Sept. 2001. Use of trade names does not constitute endorsement by the North Carolina Agricultural Research Service of the products named and does not imply criticism of similar ones not mentioned.

'E-mail address: Dick_Unrath@NCSU.edu
During the process of calibrating orchard airblast sprayers for actual TRV applications, we observed that foliage density was impacting our ability to achieve foliage drip point at calculated TRV water rates. We realized that it was not reasonable to use the same water rate per unit of TRV in trees with very different foliage densities. TRV water rates were therefore adjusted to achieve observed drip point in the top center area of trees. After we had conducted TRV sprayer calibrations and foliage density adjustments in many orchards of varied canopy configurations, a pattern began to emerge and a canopy density adjustment factor was added to the TRV calculations (Sutton and Unrath, 1984).

The TRV model gives growers a simple, objective and easy-to-use method of determining: 1) the volume of tree canopy on a given area of orchard, regardless of row spacing, tree size, age, etc.; and 2) the quantity of water and chemical to be used for dilute applications to effectively spray each particular orchard, regardless of pruning and tree canopy density. The TRV concept is based on the assumption that each row of trees is a wall of foliage and the quantity of water and/or chemical required can be related to the volume and density of foliage within that wall. The distance between rows of trees, the maximum tree height and the crossrow limb spread must be accurately measured. In addition, an assessment of canopy density is needed to calculate the TRV of an orchard.

Using these measurements, the TRV of any orchard can be calculated using the following model. 
Step 1: $\frac{10000 \mathrm{~m}^{2} \cdot \mathrm{ha}^{-1}}{\text { Crossrow spacing }(\mathrm{m})}=$ meters of row $/ \mathrm{ha}$

Step 2: Meters of row/ha (from Step 1) $\times$ tree height $\times$ cross-limb spread $=$ foliage volume $/ \mathrm{ha}\left(\mathrm{m}^{3}\right)$

Steps 1 and 2 determine the volume of foliage canopy.

Next, assess the density of the orchard according to the descriptions in Table 1.

Step 3: Select a number from Table 1 that best indicates the canopy density of each orchard or block.

The foliage volume from Step 2 and the tree density established in Step 3 are used to calculate the water volume required for a dilute spray application to provide maximum chemical load with an airblast sprayer.

Step 4: $\begin{aligned} & \frac{\text { foliage volume }\left(\mathrm{m}^{3} \cdot \mathrm{ha}^{-1}\right)}{(\text { from Step } 2)} \times \frac{\text { tree density }}{(\text { from Step 3) }} \\ = & \begin{array}{l}\text { water volume for dilute solution to be applied } \\ \text { for an application to "run-off" }\end{array}\end{aligned}$

For example, consider an orchard which has rows spaced $7.620 \mathrm{~m}$ apart, with trees $6.096 \mathrm{~m}$ high and crossrow limb spread of $5.182 \mathrm{~m}$ with a tree density of $112.59 \mathrm{~L} \cdot 1000 \mathrm{~m}^{3}$.

Step 1: $\frac{10000 \mathrm{~m}^{3}}{7.620 \mathrm{~m}}=1312.3 \mathrm{~m}$ of row $/ \mathrm{ha}$

Step 2: $\quad 1312.3 \mathrm{~m} \times 6.096 \mathrm{~m} \times 5.192 \mathrm{~m}^{3}=41,454.86 \mathrm{~m}^{3}$

Step 3: Density has been chosen as $112.59 \mathrm{~L} \cdot 1000 \mathrm{~m}^{3}$

Step 4: $\quad 41,454.86 \mathrm{~m}^{3} \times 112.591 / 1000 \mathrm{~m}^{3}$

$=4709.54 \mathrm{~L} \cdot \mathrm{ha}^{-1}$ will be needed to apply a dilute application to run-off.

However, pesticides are generally not applied to run-off. Using a $70 \%$ of the "to run-off" calculated rate reduces the dilute application just to the point of drip, or what is called "pesticide dilute". Table 2 gives the adjustments to the "TRV calculated water rates for dilute to run-off" water applications rate for various chemicals used and types of spray applications. The $4709.59 \mathrm{~L} \cdot \mathrm{ha}^{-1}$ in the example above is used to illustrate the adjustments in Table 2.

Additional research has shown that good distribution of chemical can be obtained with applications despite varying tree size and density (Sutton and Unrath, 1988).

The TRV model is accurate for chemical application with conventional airblast sprayers, using water volumes as low as $1400 \mathrm{~L} \cdot \mathrm{ha}^{-1}$. Below this volume, the physics of droplet size and impingement on the foliage can become a limiting factor in obtaining effective deposition on trees. Thus, if use of the TRV model gives a water application rate of $<1400 \mathrm{~L} \cdot h a^{-1}$, a $1400 \mathrm{~L} \cdot \mathrm{ha}^{-1}$ rate should be considered a minimum water application rate in a conventional airblast sprayer. However, use of a concentrate sprayer (higher air speed) will ensure adequate impingement of the spray solution on the tree surfaces at low water volume.

Our research and grower experience suggest that results with concentrate applications of chemical thinners differ from those with dilute sprays. As water volume decreases and chemical concentration increases, thinning activity and uniformity decreases (Table 3). At 5 times dilute, a concentrate application is much less effective than a dilute application ( $150 \%$ vs. $95 \%$ of appropriate full crop load) even though both have significant effects. At $120 \%$ of TRV, run-off reduced thinning response. This experiment and many others indicate that crop load is less uniform throughout the tree canopy following concentrate applications.

From the standpoint of application equipment techniques, uniformity of remaining crop load within the tree canopy following chemical
Table 1. Apple canopy density adjustments in tree row volume (TRV) model.

\begin{tabular}{ll}
\hline $\begin{array}{l}\text { Water vol } \\
\left(\mathrm{L} \cdot 1000 \mathrm{~m}^{3}\right)\end{array}$ & $\begin{array}{c}\text { Tree } \\
\text { characteristics }\end{array}$ \\
\hline 92.65 & $\begin{array}{c}\text { Extremely open, light visible through entire tree, } \\
<15 \text { scaffold limbs per tree or young tree } \\
\text { Very open, 18 to 21 scaffolds per tree, light penetration } \\
\text { throughout tree, healthy spurs within tree canopy } \\
\text { Well pruned, adequate light in trees for healthy spurs } \\
\text { throughout the trunk and scaffold limbs, many holes or } \\
\text { openings in foliage where light is visible through tree } \\
\text { Moderately well pruned, reasonable spur population } \\
\text { within the canopy, tree thick enough that light is not } \\
\text { visible through bottom two-thirds of tree }\end{array}$ \\
$\begin{array}{c}\text { Pruned minimally, spurs inside canopy are weak due to } \\
\text { limited light, very few openings where light is visible } \\
\text { throughout the tree }\end{array}$ \\
$\begin{array}{c}\text { Little or no pruning, spurs dead or weak in canopy, very } \\
\text { little light visible throughout the tree }\end{array}$ \\
$\begin{array}{c}\text { Unpruned, extremely thick, no light visible anywhere } \\
\text { through tree canopy, trees }>6 \text { m high }\end{array}$ \\
36.59 &
\end{tabular}

Table 2. Adjustments in apple tree row volume (TRV) calculated water rates for various chemicals and types of spray applications.

\begin{tabular}{lcc}
\hline \hline $\begin{array}{l}\text { Type of spray } \\
\text { application and/or } \\
\text { chemical application }\end{array}$ & $\begin{array}{c}\text { Calculated } \\
\text { TRV water rate } \\
\text { to be used for a } \\
\text { dilute application }(\%)\end{array}$ & $\begin{array}{c}\text { Volume } \\
\left(\mathrm{L} \cdot \mathrm{ha}^{-1}\right) \\
\text { needed in TRV } \\
\text { example orchard }\end{array}$ \\
\hline $\begin{array}{l}\text { Pesticides: } \\
\text { Pre-petalfall dilute pesticide } \\
\text { application (adjusted because of } \\
\text { incomplete foliage development) }\end{array}$ & 56 & $2637.6^{2}$ \\
$\begin{array}{l}\text { Dilute pesticide application } \\
\text { (from petal fall on) and all } \\
\text { other chemical applications } \\
\text { not specifically mentioned below }\end{array}$ & 70 & 3297.0 \\
$\begin{array}{l}\text { Thinners: } \\
\text { 'Spur Red Delicious' } \\
\text { and 'Fuji' Thinners }\end{array}$ & & \\
$\quad$ Thinners for other cultivars & 100 & 4710.0 \\
\hline
\end{tabular}

${ }^{2}$ Use of this reduced volume requires accurate nozzling to reach the tops of trees and good air displacement within trees (reduced tractor speed).

Table 3 Effect of water volume on airblast thinning response to Ethephon + Carbaryl $^{\mathrm{z}}$, with dosage constant.

\begin{tabular}{lccc}
\hline \hline $\begin{array}{l}\text { Water vol } \\
\left(\mathrm{L} \cdot \mathrm{ha}^{-1}\right)\end{array}$ & $\begin{array}{c}\text { Concentrate } \\
\text { rate }\end{array}$ & $\begin{array}{c}\text { TRV } \\
(\%)\end{array}$ & $\begin{array}{c}\text { Appropriate } \\
\text { full crop load }(\%)^{\mathrm{y}}\end{array}$ \\
\hline 0 & Control & 0 & $190 \mathrm{a}$ \\
748 & $5.0 \times^{\mathrm{x}}$ & 20 & $150 \mathrm{~b}$ \\
1497 & $2.5 \times$ & 40 & $140 \mathrm{~b}$ \\
2245 & $1.7 \times$ & 60 & $140 \mathrm{~b}$ \\
2994 & $1.2 \times$ & 80 & $110 \mathrm{~cd}$ \\
3740 & $1.0 \times$ & 100 & $95 \mathrm{~d}$ \\
4490 & $0.8 \times$ & 120 & $130 \mathrm{bc}$ \\
\hline
\end{tabular}

${ }^{2}$ Ethephon $1.875 \mathrm{~L}$ Carbaryl $2.4 \mathrm{~kg}$ per $1000 \mathrm{~L}$.

${ }^{y}$ Means separated by LSD, $P<0.05=30$.

"X"times dilute" chemical rate.

thinner response is another major factor in thinner efficacy. The TRV model objectively and accurately calculates the water volume and/or chemical load for any orchard situation, but does not address the subject of uniformity or effectiveness of delivery and distribution of the spray solution to the tree's leaf and fruit surfaces. Adjusting nozzle size and position to achieve uniform remaining copy load is a separate challenge. Proper nozzling for any chemical application will vary with tree form, height, cross row spacing, tree density, crop load and water volume applied. Tractor speed is another important variable in properly delivering the spray solution to the tree canopy. The speed must be matched to the particular sprayer's number of nozzles, air volume and air speed, of the particular sprayer being used, so that the system delivers the spray droplets into the canopy and deposits them appropriately on the leaf and fruit surfaces. 
The most frequent pattern of nonuniformity in thinner applications is excessive fruit thinning in close proximity to the sprayer and inadequate thinning farther away within the canopy. Concentrate applications generally increase this nonuniformity.

Spray distribution for chemical thinner applications becomes a much greater concern then the pesticide applications because the result of error is more serious [ie. small fruit size (under-thinning) or excessive fruit removal (over-thinning)] and because light levels related to tree canopy density also impact the amount of initial fruit set, natural drop and chemical thinning needed. Differing light levels within trees has been well documented (Heinecke, 1975). A comparison of natural and chemically induced fruit load reduction (Table 4) showed a significant difference between canopy zones for natural drop and chemical thinning plus natural drip (total drop). There were greater differences between canopy zones in natural fruit drop than in chemically induced fruit drop (calculated as total drop minus natural fruit drop). Most important of all, the percentage of fruit remaining at harvest varied from excessive in the top to about right on the lower outside to almost nil in the lower inside of the canopy.

There are both physiological and mechanical explanations for differential thinning within the tree canopy. Fruit that are better exposed are usually better pollinated, bigger and more vigorous. In addition the tops of trees are farthest from the sprayer, where air speed and displacement are lower both because of the distance and the disruption of air pattern by limbs closer to the sprayer. All these factors reduce the likelihood of adequate "top of tree" crop load reduction. In contrast, crop load on the bottom inside area frequently is reduced excessively or eliminated. To counteract these canopyzone related differences, nozzle distribution must be considered in distinct sections. The bottom third of the tree canopy is nozzled for little or no chemical delivery, relying mainly on gravity and turbulence-driven drift for what little chemical thinning, if any, is needed. The middle third of the canopy has a distinct but small amount of chemical solution (10\% to $20 \%$ ) directed as a fine mist to cover the exterior without penetrating the canopy too far. The top third of the tree receives $80 \%$ to $90 \%$ of the spray volume with larger droplet size, which targets the tree leader area with the largest nozzle and most aggressive "stream" pattern. Actual tree shape, density, cross-row spacing and initial crop load have the greatest impact on nozzle pattern.

Table 4. Effect of position of apple fruit within tree canopy on natural fruit drop, chemical fruit thinning and final fruit set ${ }^{2}$.

\begin{tabular}{lcccc}
\hline Tree & \multicolumn{3}{c}{ Fruit drop (\% flowers) } & $\begin{array}{c}\text { Fruit remaining } \\
\text { Canopy }\end{array}$ \\
\cline { 2 - 4 } Zone & $\begin{array}{c}\text { Natural } \\
\text { (unthinned) }\end{array}$ & $\begin{array}{c}\text { Chemically } \\
\text { induced }\end{array}$ & Total & $\begin{array}{c}\text { (\% flowers) } \\
\text { Top }\end{array}$ \\
To a & 41 & $81 \mathrm{~cd}$ & 19 \\
Lower outside & $57 \mathrm{~b}$ & 35 & $92 \mathrm{de}$ & 8 \\
Lower inside & $72 \mathrm{bc}$ & 27 & $99 \mathrm{e}$ & 1 \\
\hline
\end{tabular}

${ }^{x}$ Means separated by LSD $P<0.05=16$.

${ }^{\mathrm{y}}$ Chemically induced thinning calculated as total drop minus natural drop $=$ chemically induced thinning.

${ }^{\mathrm{z}}$ Fruit clusters dipped for uniform full coverage.
Dwarf, high density orchards represent a special situation for TRV applications. Most high density orchards calculated TRV water application rates are well below the minimum desirable volume for good droplet impingement $\left(<1400 \mathrm{~L} \cdot \mathrm{ha}^{-1}\right)$. We have consistently obtained improved efficacy of pesticide application and improved efficiency by calibrating for double the TRV calculated volume, which raises the water application rate above the minimum desirable volume required. Then driving every other row middle reduces water volume used back to the true TRV calculated rate. With regard to chemical thinner activity, we have found that dwarf trees have similar shade sensitivity and variability in fruit set and chemical thinning response as do larger trees (Fig. 1). Spraying every row middle at TRV rates has proven less efficient and responsive than the double TRV rate applied in every other middle.

The reality of sprayer calibration and nozzling for chemical thinner applications is that until the proper chemical load is appropriately (not necessarily uniformly) delivered and deposited on leaf and fruit surfaces, the chemicals applied cannot be considered effective for commercial thinning response.

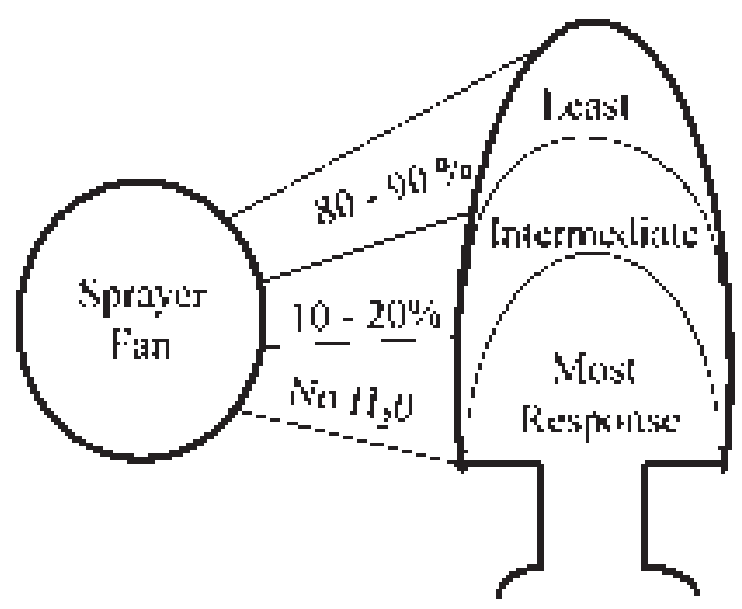

Fig. 1. Responsiveness of apple trees to chemial thinning and spray distribution compensation.

\section{Literature Cited}

Byers, R.E., K.D. Hickey, and C.H. Hill. 1968, Base gallonage per acre. Virginia Fruit 60:19-23.

Heinecke, D.R. 1975. High Density apple orchards-Planning, training and pruning. U.S. Dept. of Agr. Handbook 458:1-34.

Herrera-Aguirre, E. 1977. PhD, North Carolina State Univ., Raleigh, N.C.

Herrera-Aguirre, E. and C.R. Unrath. 1980. Chemical thinning response of 'Delicious' apples to volume of applied water. HortScience 15:43-44.

Sutton, T.B. and C.R. Unrath. 1984. Evaluation of the tree-row-volume concept with density adjustments in relation to spray deposits in apple orchards. Plant Dis. 68:480-484.

Sutton, T.B. and C.R. Unrath. 1988. A Comparison of handgun and tree-rowvolume pesticide applications. Plant Dis. 72:509-512. 